\title{
老人ならびに児童の低栄養に対する適応に関する研究 Studies on the Physiological Adaptation to Low Caloric \\ Diet in the Aged and Children.
}

（第 1 報） 低栄養老人のエネルギ一代謝と蛋白代謝

1. On the Energy and Protein Metabolism of the

Aged under Prolonged Dietary Deficit.

(昭和 34 年 9 月 15 日受理)

$$
\text { 吉川 一 弥 }
$$

(Kazuya Yoshikawa)

The relation between the physiological functions and the dietary deficit was investigated on the aged male subjects residing in the old people's home.

The daily caloric and protein intakes of the subjects were found to be about $1600 \mathrm{Cal}$ and about $55 \mathrm{~g}$, respectively in average, and the average ratio of intakes to the dietary allowances was estimated as $73 \%$ in calorie and $78 \%$ in protein.

On account of the food energy deficit, the daily acticity was diminished remarkably and the basal heat production was also lowered to $28.6 \mathrm{Cal} / \mathrm{m}^{2} / \mathrm{hr}$ in average. This was the reason why the energy balance could be kept on zero level. In parallel with the decreasing of the basal metabolism, the urinary creatinine excretion was reduced notably, and the hypoproteinemia was also detected. In contrast to these functional troubles, the loss of body weight was not revealed, which was the important symptom in the case of the adult human starvation.

From these results it was concluded that the physiological adaptation to the low caloric diet in the aged was based mainly on the decrement of the basal and protein metabolism.

低栄養の状態におかれた場合生体にどのような変化が あらわれるかについてはすでに数多くの研究がある。な かでる Benedict(1) あるいは Keys ${ }^{2)}$ らの青年について の長期隇食試験成績，またわが国では高比良 ${ }^{3)}$ の断食研 究などは貴重な資料として有名である。さらに今次大戦 によつて栄费失調症が多発し，わが国に打けるこの分野 の研究にいちじるしい進歩をあたらした4５（6)7)8)。かく て現在低栄荃時の生体の形態的, 機能的あるいは病理解 剖学的な諸变化についての知識はすこぶる広汎豐富なも のとなつている。

ところで飢餓あるいは栄養失調正にいたらない程度の 低栄飬状態，たとえば食餌量が理論的所要量に達しない

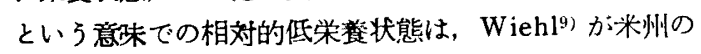
勤労者にすらその該当者を見出しているょうに, 時代, 国家のいかんを問わずつねに当面する問題である。しか もこ5した軽度の低栄荃がながくつつくと, 生体にはそ の低栄鏊レベルに応じた定常状態が成立するわけであつ て,この定常状態成立の適応過程を明かにすることに強
い関心がよせられるのである。しかしこしした立場から の研究は案外少なく，わずかに Keys ${ }^{2)}$ あるいは吉村 ら ${ }^{10)}$ が青年あるいは成人を対象として，低栄養に対する 生体の適応過程を系統つけよ5とした試みを行つている にすぎない。

さて低栄養に関する従来の研究対象はすべて青壮年期 に限られて扣り，成長期あるいは老年期を対象としたも のはきわめて少ない。ただ成長期の場合については，最 近いちじるしく関心が高まり，FAO および WHO が とくに研究班を組織して Kwashiorkor（小竖蛋白欠乏 症) の組織的研究にのり出しているが1112)，老人の場合 の研究は皆無といつてょいほど少ない。そこで筆者は老 人と児童について，低栄尊に際してあらわれる適応過程 を扣もにエネルギー代謝と蛋白代謝の面から明かにしよ うと考えた。すなわち対象を变老院老人および荃護施設 収容児童などいずれる現在の社会㬝において相対的低栄 養状態にあると思われる中からえらび，まずその低栄整 水準を決定したのち，その影鄉か体位あるいは生理機能 
にどのように現われるかを検討した。そのうち児童につ いての成績は第 2 報にゆずり，第 1 報として老人の場合 の成績について報然寸る。

\section{実 験 方 法}

対象と実験期間：大阪府下 A，B の 2 養老院に収容さ れている健康な老人の5ちから, 別に報告した食餌調査 成績13)にもとずいて，低栄蝗の状態にある被㭘者 10 名 （男性，平均年令 69 才，最低 65 才，最高 74 才）をえら んだ。対照は中流階級の一般居宅老人12名 (男性, 平均 年令 63 才，最低 60 才，最高67才）である。このほか同 じく荃老院老人男性11名についても諸検查を行つた。実 験期間は 1955 年 6 月中の 1 ケ月間である。なお対象老 人の施設収容期間は最低 1 ケ年であり，その生活に充分 馿れていたことを附言する。

食餌調査: 低栄裳老人の 1 日食聑掑取量は施設給与食 餌量と補食量とを調査して決定した。すなわちA, B 両 施設で連続 3 日間宛の告測結果にもとずいて 1 人 1 日当 り平均食剘量を決定し，一方補食は畫込み調查により推 定值を求めた。

1 日消费熱量の決定: 低栄養老人 9 名, 他に正常状態 にある施設老人 4 名計 13 名について，1 日宛被検者 1 名 につき調査員 1 名を配して正確な生活時間調查を行つ た。そして1日生活行動内容を明かにするとともに，各 人の垁測基礎代謝值および各動作の $\mathrm{R} \cdot \mathrm{M} \cdot \mathrm{R}$ 文献值 ${ }^{14)}$ を適用して 1 日消費熱量を計算した。

基礎代謝量：午前 4 時から 6 時までの早朝目をさまし たまま床の中で灾静に臥せつている条件で測定した。㹉 気は Douglas-bag 法, ガス分析は労研式分析器を用い た。なお測定は連続 2 日間笑施し，その平均值を代表值 としたが，ときには 3 ないし 4 日間連続測定をくりかえ して成績をたしかめた場合もある。

血液検査：採血は呼気採集後の基礎条件で 1 ないし 2 回矢施した。すなわち耳架採血によつてへモグロビン濃 度 (Sahli 法)，赤血球数，白血球数を，また肘静脈採血 によつて全血おょび血清比重（硫酸銅法），血清蛋白濃 度 (Kjeldahl 法)を測定した。つぎに比重值からへマト
クリット值，ついで血色素䋆数，容積係数を算出した。 なお血清蛋白蛬度は等素濃度に 6.55を乗じて求めたが， あらかじめ残余窒素睤は一律に $20 \mathrm{mg} / \mathrm{dl}$ と仮定して差 引いた。

尿中絰窒素量およびレアチニン排泄量の测定：午前 8 時を界とした 1 日全尿を 3 日間連読探集し，1 日全窒 素排泄量 (Kjldahl 法), およびクレアチニン排泄量 (Folin 改良法 ${ }^{15)}$ ) を測定した。またこの尿について榶， 蛋白, ウロビリノーダンの定性試験を行つた。

身体計測その他：早朝空腹時をえらんで体重, 脈挦 数, 呼吸数および血圧などを測定した。また昼食前に握 力, 肺活量などの体力検查を実施した。

\section{実 験 成 績}

\section{A. 低栄嘚老人の食慨摄取星}

まず対象低栄荃老人が施設給食から掑つている食餌量 を第 1 表に示した。これは 6 日間調查成續の平均值を示 したものであるが，この值は施設の年間給養資料あるい は 1 日平均 55 円という当時の食䬣眲費などから考えて， 妥当な平均給食量を示したものとみなすことができる。 また書込文調査による補食量は 1 日平均約 $50 \mathrm{Cal}$ 程度 であつた。

したがつて筆者の対解とした低栄養老人は 1 日当り熱 量䄪 $1600 \mathrm{Cal}$, 蛋白質䄪 $55 \mathrm{~g}$ （動物性，約 $20 \%$ ）を摄 取しているにすぎないのである。ところで凟源調查会食 糧部会で決定した 60 〜 才老人の栄養所要量は2200 $\mathrm{Cal}$ ，熱量蛋白質 $70 \mathrm{~g}$ である16)。したがつて対象老人は 熱量で約 $27 \%$ ，蛋白質で約 $20 \%$ 不足していることとな り,これにとるなつてカルシウム，ビタミンAおよび $\mathrm{B}_{2}$ なども当然所要量に充たない。すなわち対象老人は特定 栄養素のみの久乏ではなく，食餌量そのものの不足の状 態, すなわち低栄養の状態におかれていることが分るの である。また 60 〜 才の老人の標淮体位とその栄飬所 要量とから, 単位体表面積当り所要熱量と単位体重当り 蛋白所要量とを求め，これを対象老人のそれと比較する と，こ机は第 2 表のよ5になり，摄取不足は蛋白質でか なり消却されるが，熱量ではやはり $20 \%$ にもおよんで

第 1 表低栄落老人の給湌食慨量

(1 1 人 1 日当 $\boldsymbol{D})$

\begin{tabular}{|c|c|c|c|c|c|c|c|c|c|c|c|c|}
\hline & \multirow[b]{2}{*}{$\begin{array}{l}\text { 熱䁷: } \\
(\mathrm{Cal})\end{array}$} & \multirow{2}{*}{ 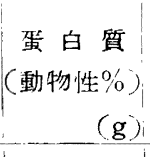 } & \multirow{2}{*}{$\begin{array}{r}\text { 脂質 } \\
(\mathrm{g}) \\
\end{array}$} & \multirow[b]{2}{*}{$\begin{array}{r}\text { 糖質 } \\
(\mathrm{g})\end{array}$} & & 成 & 分 & \multicolumn{3}{|c|}{ ビ } & \multicolumn{2}{|l|}{ ע } \\
\hline & & & & & $\begin{array}{r}\mathrm{NaCl} \\
(\mathrm{g})\end{array}$ & $\begin{array}{l}\mathrm{Ca} \\
(\mathrm{mg})\end{array}$ & $\begin{array}{l}\mathrm{Fe} \\
(\mathrm{mg})\end{array}$ & $\begin{array}{c}\text { A } \\
\text { (I.U.) }\end{array}$ & $\begin{array}{l}\mathrm{B}_{1} \\
(\mathrm{mg})\end{array}$ & $\begin{array}{l}B_{2} \\
(\mathrm{mg})\end{array}$ & $\begin{array}{r}\text { Niacin } \\
(\mathrm{mg})\end{array}$ & $\begin{array}{l}\mathrm{C} \\
(\mathrm{mg})\end{array}$ \\
\hline 全平均值 & 1,520 & $\begin{array}{c}53.7 \\
(21.6)\end{array}$ & 14.7 & 298.1 & 13.8 & 277 & 18 & 2394 & 1.10 & 0.54 & 19.4 & 55 \\
\hline
\end{tabular}

注. 調査 6 日間の平均值を示す。 
第 2 表 熱量と蛋白質の単位体表ならびに体重当り摄取量

\begin{tabular}{|c|c|c|c|c|c|c|c|c|c|}
\hline & \multirow{2}{*}{ 身 } & \multirow{2}{*}{$\begin{array}{r}\text { 長 } \\
(\mathrm{cm}) \\
\end{array}$} & \multirow{2}{*}{$\begin{array}{r}\text { 車 } \\
(\mathrm{Kg}) \\
\end{array}$} & \multirow{2}{*}{$\begin{array}{r}\text { 表 } \\
\left(\mathrm{m}^{2}\right) \\
\end{array}$} & 総 摄 & 取 量 & \multicolumn{2}{|c|}{ 单位当り熱量掑取量 } & \multirow{2}{*}{$\begin{array}{r}\text { 単位体重当 } \mathrm{y} \\
\text { 蛋白 摄取 量 } \\
(\mathrm{g} / \mathrm{Kg})\end{array}$} \\
\hline & & & & & 熱 $\begin{array}{c}\text { 量 } \\
(\mathrm{Cal})\end{array}$ & 蛋 白 $\begin{array}{c}\text { 質 } \\
(\mathbf{g})\end{array}$ & 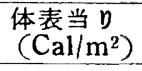 & 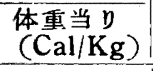 & \\
\hline 低栄養老人 & & 153.3 & 45.3 & 1.407 & 1,600 & 55 & 1137 & 35.3 & 1.21 \\
\hline 望 & & 157.5 & 53.7 & 1.543 & 2,200 & 70 & 1426 & 41.0 & 1.30 \\
\hline
\end{tabular}

注 1）食精資源調查会資料による標华体位と栄意所要量を示す。

第 3 表 基礎 代謝量

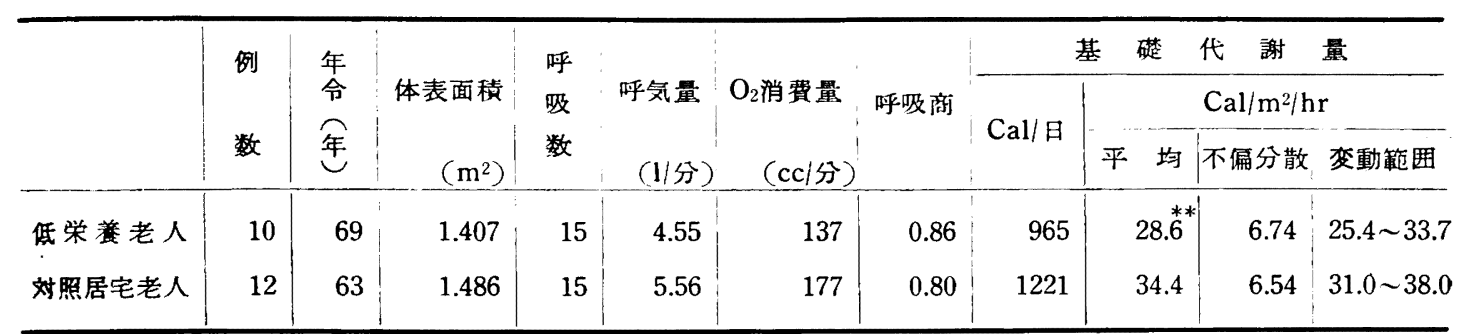

注 ** 低栄養老人值と対照居宅老人値との差が危険率 $1 \%$ で有意であることを示す。

おりこの面からす対悗老人が低栄養状態におかれてい ることがさらに確められたわけである。

以上まず対象老人の食慨䀸取量を明かにし，その低栄 養の程度を所要量と対比させて検討したのであるが，つ ぎにこうした低栄養によつて老人の生理機能にどのよう な影䇾があられるかを検討する。

\section{B. 低栄茧老人のエネルギー代謝}

1. 基碟代謝について

そこで最初に低栄養老人のエネルギー代謝について検 討するが，その5ちまず基碟代謝の成績について述べ る。低栄養老人および正常居宅老人の基礎代謝測定成績 の各平均值を求めて第 3 表に示した。これからまず居宅 老人值を 1 時間当り体表面積当りの值でみると, 平均 $34.4 \mathrm{Cal} / \mathrm{m}^{2} / \mathrm{hr}$ であつて，これは60才以上の日本人標準 値と全く一致した值である。すなわち対照老人の基碟代 謝は正常值を示しているのである。ところがこれに対し て低栄帻老人の值は平均 $28.6 \mathrm{Cal} / \mathrm{m}^{2} / \mathrm{hr}$ で, 対照に比べ ると約 $17 \%$ にあおよぶ低下となるのであり，むちろん その差は推計学的に有意である。このよ5に老人の基礎 代謝か低栄笭によつていちじるしく低下するという事夷 がまず第一に注目されたのである。

\section{2. 消費熱量と熱量出納}

低栄荖人 9 名および対照として正常条件にある施設 老人 4 名について実施した生活時間調査の成績を，その 生活行動を「労作」、「身辺雑事」、「自由期楽」および 「睡眠」に大別し，それぞれの所要時間ならびにそれに 纫した消整熱量を計算して第 4 表に示した。まず対照群 4 名は風臣屋手伝い, 饮事係などの作業に従事して普通
の勤労生活を営み，その食慨量む 1 日約 $2100 \mathrm{Cal}$ あるい はそれ以上におよんでいる。すなわちこの場合の「労 作」の平均 R.M.R.は 1.54, 所要時間は約 7.5 時間で軽 労作に担当し，その基礎代謝をみるとこれは平均約 33.0

第 4 表 低栄意老人の生活時間と消費熱量

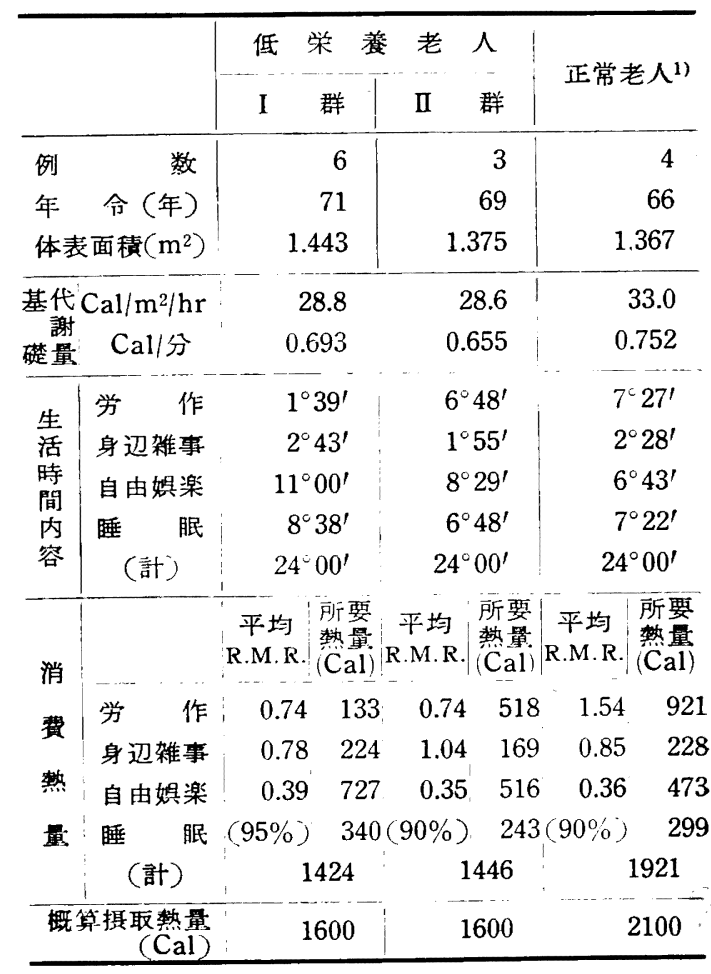

注 1）との場合の対照は施設老人ょりえらんだ。 
$\mathrm{Ca} / \mathrm{m}^{2} / \mathrm{hr}$ でほぼ正常值である。その1日消費熱量を計 算すると平均 $1921 \mathrm{Cal}$ となり，掑取熱量とほぼ平衝の とれた正常の熱量出納水準にあることがわかる。

これに対して低栄養老人は，まずその生活内容からみ て2 群に大別できる。すなわち労作 (坐業, エフのハト メ打ち）が少なく，終日部屋に閉じこもつて無為徒然の 生活を送る第 1 群と, 労作時間をはじめ時間配分からみ ると普通作業の対照群と変らない第 2 群とである。しか し後者の場合もその作業内容は紙貼り，新聞紙たたみな ぞの静的坐業である。したがつて 1 日消費熱量を計算す ると第 1 群で平均 $1424 \mathrm{Cal}$, 第 2 群で平均 $1446 \mathrm{Cal}$ と なつて両群でほとんど差をみとめない。そこで全 9 例の 平均值である約 $1430 \mathrm{Cal}$ を低栄養老人の平均 1 日消費 熱量と決定することができる。すなわち日常生活行動の 消極性といらことによつて熱量失費をいちじるしく節約 していることがわかるのである。この場合その掫取熱量 は1 日約 $1600 \mathrm{Cal}$ であるから, 摃取熱量の約 $10 \%$ を特 異動的作用に失 5 むのしても，この掑取熱量で消費熱 量 $1430 \mathrm{Cal}$ とほぼ平衡が成立することになる。

このように老人にはその低熱量椇取に応じて消費熱量 を節約するとい5ェネルギー代謝での適応がみられるの であるが，この適応，すなわち消費エネルギーの節約は すべて基礎代謝の低下゙と消極的生活行動とに基因してい る。もしかりに表中の第 2 群に属する老人の基喽代謝值 $28.6 \mathrm{Cal} / \mathrm{m}^{2} / \mathrm{hr}$ および労作強度平均 R.M.R. 0.74 が，そ れぞれ対照老人の $33.0 \mathrm{Cal} / \mathrm{m}^{2} / \mathrm{hr}$ および R. M. R. 1.54 と等しいレベルに上つたと仮定して，その 1 日消費熱量
を換算すると，「労作」の項で 207Cal，1 日基碟代謝量 で 281Cal だけ増加し，1 日消费熱量は $1934 \mathrm{Cal}$ とな るのである。これからみてる基礎代謝の低下と労作の節 約とい52つによつて，老人の低熱量水淮への適応が されていることが理解されよ 5 。

\section{C. 低栄菱老人の蛋白代謝}

1. 空素出納と蛋白代謝レペル

つぎに低栄裳老人の蛋白代謝について検討するか，そ の5ちまず空素出納の成續を述ぺる。第 5 表は 1 日全尿 について総窒素量，クレアチニンおよびクレアチン贯の 測定成績をまとめたものである。このうちまず低栄筫 の1 日総空素排泄量をみると，これは平均 $6.59 \mathrm{~g}$ (換算 蛋白量約 $41.2 \mathrm{~g}$ ）である。一方前述のよ5に食䬣蛋白量 は 1 日約 $55 \mathrm{~g}$ であるから，かりに便中窒素量を 1 日約 2

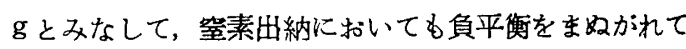
いるとみて差支えない。

つぎにこの総窒素排泄量を対照老人の平均值 $7.83 \mathrm{~g}$ と 比ぺると，これは約 $16 \%$ たけ低いといらことになる。 またクレアチニン係数は低栄着老人平均 $19.7 \mathrm{mg} / \mathrm{Kg}$, 対照老人平均 $22.8 \mathrm{mg} / \mathrm{Kg}$ であつて, 前者は後者に比べ て約 $13 \%$ の低值となつているのであるから，低栄盖老 人の蛋白代謝レペルが正常レペルに比べて低下している ことは疑いない。

2. 血清蛋白濃度その他

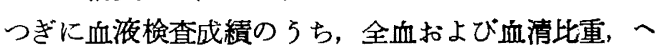
モグロビン濃度および血清蛋白濃度についてまとめた結 果を第 6 表に示した。まず血清蛋白浱度をみると，居宅

第 5 表窒素ならびにクレアチニン排泄量

\begin{tabular}{|c|c|c|c|c|c|c|c|c|c|c|}
\hline & \multirow{2}{*}{$\begin{array}{l}\text { 例 } \\
\text { 数 }\end{array}$} & \multirow{2}{*}{$\begin{array}{l}\text { 年 } \\
\text { 令 } \\
\text { (年) }\end{array}$} & \multirow[b]{2}{*}{$\begin{array}{l}\text { 尿 量 } \\
(\mathrm{ml})\end{array}$} & \multirow[b]{2}{*}{$\begin{array}{r}\text { 総窒素量 } \\
(\mathrm{g})\end{array}$} & \multicolumn{3}{|c|}{ クレアチニン排泄量 } & \multirow{2}{*}{$\left|\begin{array}{r}\text { クレアチ } \\
\text { ン排 泄 量 } \\
(\mathrm{mg})\end{array}\right|$} & \multirow{2}{*}{ 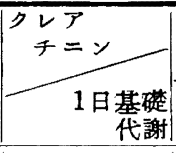 } & \multirow{2}{*}{$\begin{array}{l}\text { クレアチニ } \\
\text { ン保数 } \\
\text { 体表当 } \eta 1 \text { 時間 } \\
\text { 当り基礎代县 } \\
\end{array}$} \\
\hline & & & & & $\begin{array}{r}\text { 一日全量 } \\
\text { (mg) }\end{array}$ & $\begin{array}{l}\text { 係 数 (不偏 } \\
(\mathrm{mg} / \mathrm{Kg})\end{array}$ & 分散 & & & \\
\hline 低栄養老人 & 10 & 69 & 1253 & 6.59 & 901 & 19.7 & $2.51)$ & 97 & 0.93 & 0.69 \\
\hline 対照居宅老人 & 8 & 64 & 1084 & 7.83 & 1030 & 22.8 & $2.21)$ & 121 & 0.86 & 0.67 \\
\hline
\end{tabular}

注 * 差が危険率 $5 \%$ で有意であるととを示す。

第 6 表 血清蛋白濃度、へモグロビン濃度扣よび血液比重

\begin{tabular}{|c|c|c|c|c|c|c|c|c|c|c|}
\hline & \multirow{2}{*}{ 例 } & \multirow{2}{*}{ 数 } & \multirow{2}{*}{$\begin{array}{r}\text { ヘモグロ } \\
\text { ピン濃度 } \\
(\mathrm{g} / \mathrm{dl})\end{array}$} & \multicolumn{3}{|c|}{ 血 清 蛋 白濃 度 } & \multicolumn{2}{|c|}{ 血液比重 } & \multicolumn{2}{|l|}{ 計 算 } \\
\hline & & & & $\begin{array}{r}\text { 平均 值 } \\
(\mathrm{g} / \mathrm{dl})\end{array}$ & 不偏分散 & 変動範囲 & 全 血 & 血 清 & $\mid$\begin{tabular}{r|} 
血清蛋白隻度 \\
$(\mathrm{g} / \mathrm{dl})$
\end{tabular} & 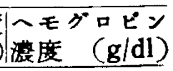 \\
\hline 低栄養老人 & & 10 & 12.9 & $\begin{array}{r}* \\
6.28\end{array}$ & 0.055 & $5.96 \sim 6.58$ & 1.052 & 1.024 & 6.39 & 13.0 \\
\hline 対照居宅老人 & & 11 & 13.4 & 6.54 & 0.077 & $6.12 \sim 7.08$ & 1.054 & 1.026 & 6.81 & 13.6 \\
\hline
\end{tabular}

注 1) 比重值より計算によつて求めた值を示した。 差が危険率 $5 \%$ で有意であるととを示す。 差は推計学的に無意。 
老人では平均 $6.54 \mathrm{~g} / \mathrm{dl}$ でやや低いか，これはその採血 が起床前空腹安静の条件で行われたことを考えれば，ま す正常濃度を䊒持しているとみなしてよい。ところが低 栄群では平均 $6.28 \mathrm{~g} / \mathrm{dl}$ となつて，対照に比べて明か に低く，しかもその差は推計学的に有意である。この血 清蛋白淃度の低值であることだけで，低栄養老人が低蛋 白血症に陷つていると断定することは早計であるにして も，正常老人の値との対比からみて少くとも低蛋白血症 の傾向にあることは否定できない。たたここの場合へモグ ロビン濃度す低值ではあるか，これは対照老人も同様で あつて，生理的老人性賀血の一般的特性によるものであ り，これを蛋白欠乏の指䐼と考えることはできない。つ ぎに全血ならびに血清比重においても，之もに低栄養群 が低值を示し，これから計算によつて求めた血清蛋白濃 度ならびにーモグロビン濃度の值が実測值とほぼ一致し た傾向を示したことを附言する。

以上要するに登素出納は食飭蛋白量に応じたやや低い レヘルなからら零平衡を維持しているとはい5ものの, 蛋 白代謝レベル自体は低下し，また血液䠉蔵蛋白の減少傾 向をまねいていることがわかつたのである。たたここうし た血清蛋白濃度減少の原因が，食蛋白不足の直接的なむ のか，あるいは熱量不足を第一義とした間接的なもので あるかについては，ここで断定することはできない。

\section{D. 老人における基潒代謝と蛋白代謝の関係}

さきに低栄養老人の基礎代謝と蛋白代謝がともに低下 している事実を明かにしたか，つぎにこうした低下に際 して両者の間にどの上うな関係か成立するかを検討す る。そのため低栄養対象 10 例を含めた養老院老人 21 例 および居宅老人 12 例計 33 例の全测定例数の5ち，基礎 代謝とクレアチニン排泄量の両測定值の対応ある30例に ついて，その結果を便宜上，体表面積当り基碟代謝量の 高低の順に配例して第1困に示した。またこの図で基礎 代謝值 $30 \mathrm{Cal} / \mathrm{m}^{2} / \mathrm{hr}$ 扎よび $34 \mathrm{Cal} / \mathrm{m}^{2} / \mathrm{hr}$ を界として全 例を基碄代謝の高低差による 3 群に分ち，各群の諸測定 成績の各平均値を記入した。

まずこの図で体表当り基礎代謝は最高 $38.0 \mathrm{Cal} / \mathrm{m}^{2} / \mathrm{hr}$ から最低 $25.4 \mathrm{Crl} / \mathrm{m}^{2} / \mathrm{hr}$ で，30\%以上に执よぶ大きい变 動をしていることが目立つが，一方クレアチニン係数す ほぼれと平行して変動している。この平行関倸はクレ アチニン保数と基礎代謝 $\left(\mathrm{Cal} / \mathrm{m}^{2} / \mathrm{hr}\right)$ との比をとると， その変動の幅が消却されて四にみるよ5にほぼ直線的と なることからす理解できるが，さらにこれをたしかめる ため画者の相関々倸を検討すると第 2 四のようになる。 すなわち基碟代謝 $\left(\mathrm{Cal} / \mathrm{m}^{2} / \mathrm{hr}\right)(\mathrm{X})$ とクレアチニン俰 数 $(\mathrm{Y})$ との間には $\mathrm{X}=18.69+0.648 \mathrm{Y}$ または $\mathrm{Y}=12.70$ $+0.255 \mathrm{X}$ の関係式が成立し，その相関保数 $(r)$ は +0.407
第 1 図基礎代謝とクレアチニン代謝との関倸

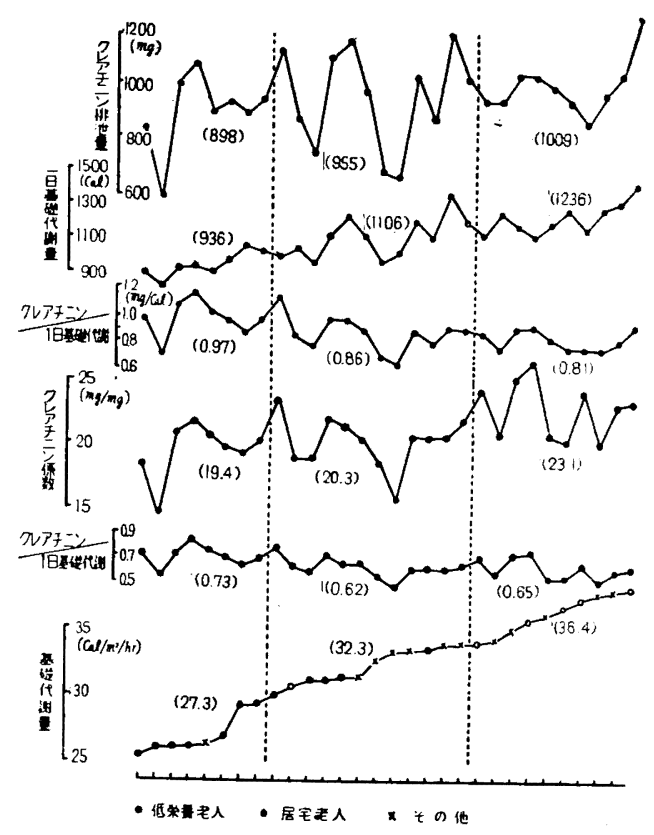

第 2 四基礎代謝とクレアチニン代謝の相閣関係

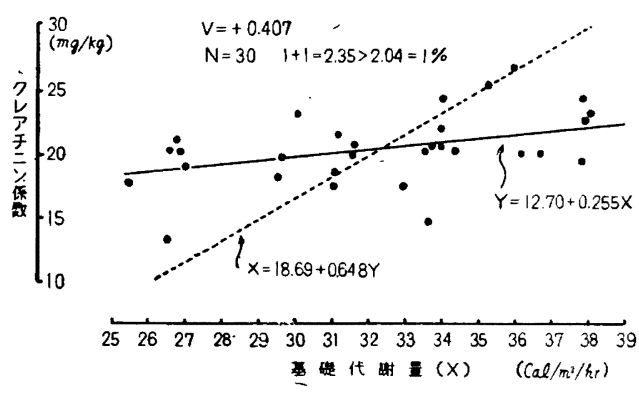

で $1 \%$ 以下の危険率で有意性のある順相関を証明するこ とができる。このことは老人の基礎代謝の変動, この場 合括すに基礎代謝の低下は必然的に蛋白代謝の低下を招 くものであることを物語つている。つまり低栄盖老人に おいてみられた蛋白代謝と基礎代謝の低下は, 老人の細 胞酸化機能減退の 2 面現象として常に相平行してあらわ れるものであることがわかつた。これは井上17)が成人男 子の場合に証明した事咨を一致する。

ここでも5一つ與味ある事夹がみられる。それは1日 全クレアチニン量と 1 日基礎代謝量（Cal/日）との比 $(\mathrm{mg} / \mathrm{Cal})$ をとると，これは第 1 図でみるよ5に体表当 り基礎代謝 $\left(\mathrm{Cal} / \mathrm{m}^{2} / \mathrm{hr}\right)$ とは逆の関係になることかわ かる。そこで体表当り基礎代謝 $\left(\mathrm{Cal} / \mathrm{m}^{2} / \mathrm{hr}\right)(\mathrm{X})$ とこの 比 $(\mathrm{mg} / \mathrm{Cal})(\mathrm{Y})$ との相関々係を検すると， $\mathrm{X}=44.95$ -14.52Y または $\mathrm{Y}=1.41-0.0166 \mathrm{X}$ の関係式が成立し, 
$r=-0.479$ (有意水潐 $1 \%$ ) の逆相関々係が証明された。 このことは体表当り基礎代謝の低いるの，つまり細胞酸 化機能の減退しているものほど，1日基礎代謝量，つま り総細胞酸化量に対する蛋白代謝量の比率が大であると 解することができるのである。すなわち低栄養によつて 老人の細胞機能が隇退する場合, 蛋白代謝を含めた全酸 化機能が低下寸ることになるか，その低下の度合は蛋白 代謝で軽度である。つまり蛋白代謝に相対的安定性がみ られるということになるのである。

要するに低栄盖状態におかれた老人では細胞機能の減 退のあらわれとして基礎代謝と蛋白代謝が相平行して低 下寸るものであるが，その5ち蛋白代謝の低下度はやや 軽るくてす气傾向がみられたといらことになる。基礎代 謝と蛋白代謝とが質的には同傾向の，しかも量的には一 定の差をもつて変動するとい5ことは, それが老人の低 栄養の場合のみにみられるものかどうかは別として大変 興味梁、事実であるといえよ5。

\section{E. 身体検査成績その他}

最後に一般身体所見，体力および血液成分などを検し た成績を第 7 表拈よび第 8 表にまとめた。まず第 7 表で 低栄盖老人の身長, 体重をみると居它老人に比べてやや 劣つている。その5ち体重差は約 $7 \%$ となるが，これを 比体重として比較するとその差はわずか $4 \%$ 程度にすぎ ない。したがつてこの体重の差は体格自体の大小による もので市つて，とくに低栄篮のために招来された差と考 えなくてよい。つまり老人においては低栄養の影锌が基 礎代謝和蛋白代謝などの機能面に強くあらわれるが, 体 重減少という形態的の面にはほとんどあらわれていない のであつて, これは成人の場合, あるいは第 2 報で述べ
る婜䫓の場合と比べていちじるしく異つた所見であり重 要である。

つぎに血圧では最高, 最低および脉圧のいずれる対照 に比べてやや高い值となり，高平均年命による脉管系の 変化か推測せられるが，とくに心機能低下を思わせる前 見はみられない。また筋力では握力で左右平均約 $13 \%$ の低下をみとめるが，これは体格の小さいこと，平㚬年 令の高いことおよび基礎代謝の低下などの諸因子か影渵 していると考えられる。しかし肺活量ではこ5した差を みとめなかつた。

また血液成分の成績を第 8 表でみると，まず赤血球 数, 白血球数で両者間に有意差がなく，とすに成人值と 比べると低い值である。一方へモグロビン漊度は前にる 述べたよ5に，低栄養群平均 $12.9 \mathrm{~g} / \mathrm{dl}$, 居宅老人平均 $13.4 \mathrm{~g} / \mathrm{dl}$ で一様に減少している。しかしへモグロビン浱 度低下とともに，赤血球数扰よびへマトクリット值る低 值であるから，色素係数怙よび容積俰数はいずれるはぼ 正常值となる。したがつてここにみられる䫎血は正常䚀 胞性，正常色素性であり，尼子ら18)の生理的老人性蚠血 に一致するるのである。

以上低栄養老人の一般身体所見は居宅老人と比べてと くにひどく電曲しているとはみとめがたいのであつて, これはェネルギー代謝あるいは蛋白代謝などの重要な生 理機能に明かな影響をみとめたことと対比して考えると その意義は大きいといわねばならない。

\section{考察}

以上の成績をまとめるとつぎのようになる。まず対象 にえらんた低栄盖老人の摄取食慨は熱量的 $1600 \mathrm{Cal}$, 蛋

第 7 表 身体検查成績

\begin{tabular}{|c|c|c|c|c|c|c|c|c|c|c|c|c|c|}
\hline & \multirow{2}{*}{$\begin{array}{l}\text { 例 } \\
\text { 数 }\end{array}$} & \multirow{2}{*}{$\begin{array}{l}\text { 年 } \\
\text { 令 } \\
\text { (年) }\end{array}$} & \multirow{2}{*}{$\begin{array}{r}\text { 長 } \\
(\mathrm{cm})\end{array}$} & \multirow{2}{*}{$\begin{array}{r}\text { 体 重 } \\
(\mathrm{Kg})\end{array}$} & \multirow{2}{*}{$\begin{array}{r}\text { 比体重 } \\
(\%) \\
\end{array}$} & \multirow{2}{*}{ 脈搏数 } & \multirow{2}{*}{ 呼吸数 } & \multirow{2}{*}{$\begin{array}{c}\text { 血 } \\
\text { 最高 }\end{array}$} & \multicolumn{2}{|c|}{ 压 $(\mathrm{mmHg})$} & \multicolumn{2}{|c|}{ 握 $\begin{array}{r}\text { 力 } \\
(\mathrm{Kg}-\mathrm{m})\end{array}$} & \multirow{2}{*}{$\begin{array}{r}\text { 肺活式 } \\
\text { (1) } \\
\end{array}$} \\
\hline & & & & & & & & & 最低 & 脈压 & 右 & 左 & \\
\hline 低栄僐老人 & 10 & 69 & 153.3 & 45.3 & 29.5 & 57 & 15 & 139 & 82 & 57 & 27 & $27^{\circ}$ & $2.33^{\circ}$ \\
\hline 刘照居宅老人 & 12 & 63 & 158.2 & 48.7 & 30.8 & 58 & 15 & 129 & 80 & 49 & 32 & 29 & 2.31 \\
\hline
\end{tabular}

注。低栄粯老人值を対照值との間の差が推計学的に無意なととを示す。

第 8 表 血夜 成 分 測定成 䋶

\begin{tabular}{|c|c|c|c|c|c|c|c|c|}
\hline & 例 & 数 & 白血球数 & 赤血球数 & 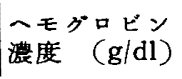 & クマット & 色素保数 & 容栍係数 \\
\hline & & & & $\times 10^{4}$ & & & & \\
\hline 低类悬老人 & & 10 & $4930^{\circ}$ & $393 ̊$ & 12.9 & 39.0 & 1.05 & 1.00 \\
\hline 対照居宅老人 & & 11 & 5071 & 424 & 13.4 & 40.2 & 1.02 & 0.96 \\
\hline
\end{tabular}

注 。両者の差が推計学的に無意なととを示す。 
第 9 表 低栄独による老人の機能ならびに体力の低下

\begin{tabular}{|c|c|c|c|}
\hline & $\begin{array}{l}\text { 然常老人 } \\
\text { 照 }\end{array}$ & $\begin{array}{l}\text { 栄 } \\
\text { 老 }\end{array}$ & $\begin{array}{l}\text { 对照に奶 } \\
\text { する增減 } \\
\text { 比率(\%) }\end{array}$ \\
\hline 重 $(\mathrm{Kg})$ & 48.7 & 45.3 & -7.0 \\
\hline 比体重 & 30.8 & 29.5 & -4.2 \\
\hline 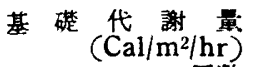 & 34.4 & 28.6 & -16.9 \\
\hline $\begin{array}{r}\text { クレチチ三ン保数 } \\
(\mathrm{mg} / \mathrm{Kg})\end{array}$ & 22.8 & 19.7 & -13.3 \\
\hline $\begin{array}{r}\text { 握力:左右平均 } \\
\text { (Kg-m) }\end{array}$ & 31 & 27 & -12.9 \\
\hline 肺 活 量 (1) & 2.31 & 2.33 & +0.9 \\
\hline 眽 搏 数 & 58 & 57 & -1.8 \\
\hline 血 (最 高 & 129 & 139 & +7.7 \\
\hline 而 $\{$ 最 低 & 80 & 82 & +2.5 \\
\hline$(\mathrm{mmHg})$ (脈 圧 & 49 & 57 & +16.3 \\
\hline 白血球数 $\left(\mathrm{mm}^{3}\right)$ & 5071 & 4930 & -2.8 \\
\hline 赤血球数 $\left(\mathrm{mm}^{3}\right)$ & $424 \times 10^{4}$ & $393 \times 10^{4}$ & -7.3 \\
\hline $\begin{array}{r}\text { ヘモグロビン澈度 } \\
(\mathrm{g} / \mathrm{dl})\end{array}$ & 13.4 & 12.9 & -3.8 \\
\hline ヘマトクリット值 & 40.2 & 39.0 & -3.0 \\
\hline 色 素 係 数 & 1.02 & 1.05 & +2.9 \\
\hline 容 穔 係 数 & 0.96 & 1.00 & +4.1 \\
\hline 血清蛋白浱度 $(\mathrm{g} / \mathrm{dl})$ & 6.54 & 6.28 & -4.0 \\
\hline 摄取（熱 量(Cal) & $(2200)$ & 1600 & -27.3 \\
\hline 食飰 蛋白質 （g） & (70) & 55 & -21.5 \\
\hline 尿中維窒素量（g） & 7.83 & 6.59 & -15.9 \\
\hline
\end{tabular}

注（）内は栄湌所要量值を示す。

白質約 $55 \mathrm{~g}$ であつて，これを所要量に比べると食剘不 足の程度は約 $20 \%$ 程度とみなされた。こ 险レベルの低下にともなつて老人にあらわれた身体的所 見を対照一般老人と比較して要約すると第 9 表のようで ある。これでなによりも印象的なのは，体表当り基礎代 謝とクレアチニン保数に著明な低下がみられること，体 重ことに比体重の差がわずかであること，この 2 点であ る。その他では血清蛋白濃度と握力に差をみとめるほ か脉管系，血液成分などに著変をみとめないとい5結果 になる。つまり対象老人は，まずその生活行動の消極性 と代謝機能の低下とによつて低熱量掑取レベルに適応し ているのであつて，この場合体重その他の形態的消耗は ほとんどみられないが，みられてす軽度にすぎいので ある。これが老人の低栄養適応に怙けるいらじるしい特 色なのである。

これに対して成人の場合の低栄䔲適応の第一段階か体 重减少であることは㸡知のと扤りである。たとえば吉 村10)は熱量 $1150 \mathrm{Cal}$, 蛋白質 $35 \mathrm{~g}$ とした減食試験で, まず体重減少（1ケ月後で約 $10 \%$ 減）ついで基礎代謝 の低下が扣こることを報告している。また Keys 2) は青 年で $1750 \mathrm{Cal}$ ，蛋白 $55 \mathrm{~g}$ という標準量の約 $55 \%$ にすぎ
ない実験食饂を与えて長期隇食試駼を行つた結果，体重 減少と基碟代謝の低下がともに著明であること，また体 重減少，すなわち体成分の消耗にともなつて必然的に筋 力, 心機能などの著明な低下゙を招くに至つていることを 述べている。すなわち成人の減食詿跧によると，低熱量 水準への適応には身体消耗と生理機能低下とが相ともな つているのであつて，とくにその一方のみの变化にとど まることはありえない。これか筆者の老人の成績といち じるしく異つた点である。

ただここで注意すべきことは筆者の対鱼はいわゆる軽 度の自然慨餓ともいらべき条件におかれており，低栄養 に適心してその低熱量水淮で定常状態を推持しているの であるか，吉村, Keys らは対象を正常栄養から急性彾 餓の状態におきかえて，その後定常状態に達するまでの 動的な適応過程をみているといらことである。このよ5 に実験条件がちがつているのであるが，しかし自然䬣餓 においても成人の場合はエネルギー消費の自発的節約と 同時に，つねに相当度の身体消耗をま祔れることはで きないのであつて，これは垁験的滅食試験の結果と同様 である。これに対して筆者の場合では身体消耗はほとん どみないで，基碟代謝の低下と行動の自発的節約だけに よつて，20\%以上にも扰よぶ低熱量水準に適応している のであつて，この成績は単に垁駼条件の相違とか，食餌 不足の程度如何とかによるものではなく，老人と成人と では低栄差適応の過程自体に差のあることによるものと 理解すべきであろう。ただし老人の場合身体消耗が皆無 だというのではない。すでに触れているように，軽度の 身体消耗は当然ともなつているのであるか，これを代謝 機能の低下と対比すると問題とするに足りない程度であ つたというにすぎない。

要するに一般に低栄養に際しては当然身体消耗と機能 低下とは同時に相ともな5ものであり，この点では老人 と成人とで質的な差異があるとは考えられない。筆者は ただその影響のあらわれ方に量的な，あるいは時間的な 差異があつて，老人の場合は機能低下の面にとくに著明 である点を指摘したいのである。なお老人における代謝 機能のこのような易変動性の成因が何であるかは, 興味 ある研究課題として今後に残された問題であろう。

$$
\text { 要 䄪 }
$$

1955年初夏，嶣老院に収容されている老人の5ち低熱 量摄取の被梌者 10 名をえらび，その身体所見ならびに 二, 三生理機能を検討してつぎの成績をえた。

1) 低栄養老人の平均食䬣摄取量は 1 人 1 日当り熱量 約 $1600 \mathrm{Cal}$ ，蛋白質約 $55 \mathrm{~g}$ （動物性約 $20 \%$ ）であり， その所要量に対する不足の程度は熱量で約 $27 \%$, 蛋白質 
で約 $20 \%$ であつた。

2）低栄養老人の基礎代謝は平均 $28.6 \mathrm{Cal} / \mathrm{m}^{2} / \mathrm{hr}$ で, 対照居宅老人の平均值 $34.4 \mathrm{Cal} / \mathrm{m}^{2} / \mathrm{hr}$ に比べて約 $17 \%$ の低下となる。またその生活行動はきわめて静的消極的 であるためエネルギー消費の自発的節約がいらじるし い。これらの結果その平均 1 日䓡量消費は約 1430Cal と なり，したがつて低熱量椇取に応じて熱量出納の平衡が 保たれていることがわかつた。

3）尿中 1 日総哇素排泄量は平均 $6.59 \mathrm{~g}$ であつて窒素 出納もまた零平衡を維持していると考えられたが，一方 クレアチニン保数は平均 $19.7 \mathrm{mg} / \mathrm{Kg}$ で対照老人の平均 值 $22.8 \mathrm{mg} / \mathrm{Kg}$ に比べて約 $13 \%$ の低値となり, 蛋白代 謝レベルは基礎代謝同様いちじるしく低下している。 また血清蛋白濃度は平均 $6.28 \mathrm{~g} / \mathrm{dl}$ で対照值 $6.54 \mathrm{~g} / \mathrm{dl}$ に比べて低く，低蛋白血症の傾向にあることがわかつた。

4）なお老人の基礎代謝と蛋白代謝は低栄粯に際して 密接に相平行して低下するものであり，两者の変動には 有意な相閣々係が証明された。

5）一方，低栄養老人の体重減少はきわめて軽度であ り，筋力，心機能女るいは血液細胞成分などにもいちじ るしい影踷はみられなかつた。

6）以上から老人の低栄養水準人の適沁は, 打もに生 活行動の消極性，ならびに代謝機能の低下に基くもので あり，これを成人の場合と比べると身体消耗をほとんど ともなつていない点でいちじるしく特幑的であることが 解つた。

終りに御指導を賜つた井上五郎教授をはじめ，終始御 援助下さつた小石助教授，新山請師の諸先生に南心より 謝意を表します。

\section{文葫}

1) Benedict, F.G., Miles, W. R. ,Roth, P. \& Smith, A. M. : Human Vitality and Efficiency under Prolooged Restricted Diet, Publication 280 Carnergie Institution of Washing. ton. 1919.

2) Keys, A. : J. Am. Diet. 22, 582, 1946.

3）高比良英雄：断食研究（岩波書店） 1930.

4) 井上 硬：日本人の栄娽, 1948

5） i. 平野交雄, 高橋 実: 栄䓹食糧学会誌, 1, $23,1948$.

ii. 中村 隆他 7 名: 同上, 1，85，1948.

6) 飯塚直彦：日本人の栄養扣よび栄美失調症（日 本医書出版)，1947.

7) 福井忠孝: 減食, 厚生科学䄅刊第三輯(創元社) 1944.

8）米沢 猛：京府医大誌 45, 113，1949.

9) Wiehl, O.G. : Milbank Mem. Fund Quart. 20, 329, 1942 (Elvehjem Handbook of Nutritionより引用)

10) i. 吉村寿人：日新医学 36, 495. 554, 1949. ii。吉村寿人：栄䅈学 (朝倉書店) 457, 1955.

11) i. Brock, J. F. \& Autret, M.: Kwashiorkor in Africa, FAO Nutritional Studies No.8, 1952.

ii. Autret, M. : Sindrome Policarencial Infantil (Kwashiorkor) and its Prevention in Central America, FAO Nutritional Studies No. 13, 1955

iii. Waterlow, J. C.: Protein Metabolism, University Press, Cambridge (Proceedings and Conference in Jamaica, 1953), 1955.

12）井上五郎：臨床栄養 9, 1, 1956.

13）井上五郎他：大阪市大家政紀要 3, 153, 1956.

14）鉿木慎次郎：労働のエネルギー原則(誠交堂), 1948.

15）井上五郎, 小石秀夫：医学々生物学 41, 28, 1956.

16）食糧盗源調查会編：日本人心栄養所要量に閣す る解説 (資源調查会資料第39号) 1954.

17）井上五郎：日本生理誌 16，216，326，1954.

18）尼子富士郎他：日本内科誌 17, 463, 477, 1929. (大阪市立大学家政学部栄養生理学教室)

（経費著者结担）

\section{アイスクリームの中の大腸菌測定に細菌滤過器を使う方法}

アイスクリーム中の細菌を分離するのに細菌濾過器を 使用し，このさい湿潤剤 Triton X-100を併用して混 在する脂肪分にさまたげられずに分離できた。これによ つて㕍䌅がのでかれるので良来判定に誤りをきたすこと のあつた原因を去り，かつ長時間を要していた大腸菌属

\section{細菌の測定が1日でできる。}

Estimation of Coliform Bacteria in Ice Cream by Use of the Membrane Filter, L. A. Nutting, P. C. Lomot, and F. W. Barber: Applied Microbiol. 7, No.4, 196 (1959)

(津村)

Threonine を含む培養液中の Isoleucine の生成

Threonine を唯一の荎素源とする合成培地に Streptomyces rimosus を培養すると， threonine の $17 \%$ にあたる isoleucine が生成した。微最の alanine を 添加すると，この合成は促進され $25 \%$ に達した。種々 の变異株を用いた実験からら+threonine は isoleucine
のブレカーサーと考えられ，アイソトーブを使用してこ のことを確諮した。

Formation of Isoleucine in Culture Media Containing Threonine, I. Horvath, I. Gado, and A. Szentirmay: J. Bucteriol. 78, 293 (1959) (津村) 